\title{
新时期自然生态空间综合管控研究
}

一以粤港澳大湾区为例

\author{
黄世金蔡云楠 ${ }^{*}$, 梁芳婷 \\ 广东工业大学建筑与城市规划学院,广州 510090
}

\begin{abstract}
摘要:梳理国内外自然生态空间管控理论得出,针对自然环境症状的管理方式不足以解决自然生态空间的整体性与复合性问 题,研究提出综合多学科理论和多种空间管制规则,对全域自然生态空间的多元生态要素进行综合管控是生态空间管控的发展 趋势。为探究自然生态空间综合管控的思路, 以粤港澳大湾区为例,分析大湾区自然生态空间总体特征和主要城市的管制措施 与特色,指出在增长背景下湾区自然生态空间管控中生态保护与社会发展之间存在的关键问题及产生的原因,针对性地提出大 湾区自然生态空间管控的目标、层次、手段、部门、主体层面的转变方向,并详细探讨从湾区自然生态空间的生态服务功能、生态 空间分级分类、动态管控指标、区域协同联动机制、空间管控权益主体等方面实施综合管控的具体思路, 以促进湾区自然生态空 间用途管制效力的提升。
\end{abstract}

关键词 : 自然生态空间;综合管控; 粤港澳大湾区

\section{Comprehensive control of natural ecological space in the new era: A case study of Guangdong-Hong Kong-Macao Greater Bay Area}

\author{
HUANG Shixin, CAI Yunnan * ,LIANG Fangting \\ School of Architecture and Urban Planning, Guangdong University of Technology, Guangzhou 510090, China
}

\begin{abstract}
After combing the natural ecological space management and control theories at home and abroad, it is concluded that factors such as physical geography, social economy, and land use changes jointly affect the material circulation, energy flow, biological migration and other key ecological processes of the natural ecological space. In the past, management methods for natural environmental symptoms were insufficient to solve the problems of the integrity and complexity of natural ecological spaces, this research puts forward comprehensive multi-disciplinary theories and multiple space control rules, comprehensive management and control of the multiple ecological elements of the entire natural ecological space is the development trend of ecological space management and control. In order to explore the idea of comprehensive management and control of natural ecological space, taking the Guangdong-Hong Kong-Macao Greater Bay Area as an example, it analyzes the characteristics of the natural ecological space in the Greater Bay Area, such as rich ecological elements, diverse ecological patterns, diverse control systems, and complex development interests. At the same time, it analyzes the control measures and characteristics of the major cities in the Guangdong-Hong Kong-Macao Greater Bay Area, and points out that in the context of growth, the following key issues and their causes exist in the management and control of the natural ecological space in the Guangdong-Hong Kong-Macao Greater Bay Area: (1) Extensive guidelines for construction activities and reduced ecological service functions; (2) Inconsistent ecological space classification standards and low efficiency in the
\end{abstract}

基金项目: 国家自然科学基金面上基金项目(51978173);国家自然科学基金青年基金项目(51708127)

收稿日期:2020-05-24; 采用日期:2021-04- 18

*通讯作者 Corresponding author.E-mail: caiyunnan2000@163.com 
use of ecological land; (3) Separation of powers for space management and control, and insufficient ecological management and control; (4) Shared participation mechanism is not yet available perfect and so on. It is pointed out that the natural ecological space in the Guangdong-Hong Kong-Macao Greater Bay Area should be strengthened to enhance the overall protection of the functional value of the natural ecological space; focus on the connection and refinement of multidimensional spatial classification; consider the development needs of cities and counties, and reserve flexible growth space to ensure ecological protection and protective utilization are equally important in the natural ecological space. It also discusses in detail the specific ideas for implementing comprehensive management and control from the ecological service functions of the natural ecological space in the Bay Area, the classification of ecological spaces, dynamic management and control indicators, regional coordination and linkage mechanisms, and space management and control rights and interests, so as to promote the enhancement of the control effectiveness of natural ecological space in the Guangdong-Hong KongMacao Greater Bay Area.

Key Words : natural ecological space; comprehensive control; Guangdong-Hong Kong-Macao Greater Bay Area

自然生态空间是以自然资源为核心要素的多功能地域空间,是我国生态文明建设的重要载体,其提供的 生态产品和生态服务具有经济-社会-生态综合效益 ${ }^{[1-2]}$ 。针对城镇化进程中不当的大规模建设活动导致的自 然生态空间破碎、生态功能降低等一系列问题 ${ }^{[3]}$, 综合运用政策法规和规划管控手段指引自然生态空间布局 和建设指标落地,逐渐成为完善自然生态空间治理体系的重要手段。

国内外学者对自然生态空间管控进行了多层次研究和分析 (表 1)。国际上一般认为自然生态空间规划 管控是对民主和多元化空间的健康公平与环境正义等问题的协调 ${ }^{[4-5]}$, 主要通过行动主义和决策来对抗环境 高档化 ${ }^{[6]}$, 并非禁止任何开发活动的进人。国外自然生态空间规划管控研究多以协调性、多功能、连通性、多 尺度规划、多样性和认同感作为基本原则 ${ }^{[7-9]}$, 将人的身心健康和视觉、知觉感知的人本主义方法、景观生态 学的多尺度方法等手段应用于生态空间管控, 解决从地块到城市地区再到国家多个层面的生态问题 ${ }^{[10]}$ 。总 体而言, 自然生态空间管控能作为体现城市可持续发展和民众对自然空间使用意愿的政策工具 ${ }^{[11]}$, 为城镇和 乡村之间的绿色和蓝色空间网络提供多种社会、经济和生态效益 ${ }^{[12]}$ 。

国内多以自然保护区等点状区域、生态廊道等线状区域以及草原、海域等面状区域为研究对象,探究自然 生态空间中生态用地保护与利用的协调机制 ${ }^{[13-14]}$ 。研究认为, 自然生态空间用途管控是对生态空间相对独 立的区域范围及保护其生态属性不改变的总体管制 ${ }^{[15]}$ 。自然生态空间并非无人区, 需从“物” 和“人”两个视 角综合考虑, 结合系统工程学、人居环境学、景观生态学等多维度的学科理论, 重点探讨自然生态空间整体效 应的系统性、要素互联的关联性、系统反馈调节的可控性三大重要特征 ${ }^{[16]}$ 。在生态空间结构层面,从生态网 络系统、区域空间发展布局、生态补偿机制、绿色产业体系建设四个方面探究区域的组合模式能促进自然生态 空间结构的优化 ${ }^{[17]}$; 在生态空间管控效益层面,通过 “分区管制”, 将刚性和弹性两种管控模式引人自然生态 空间管控,控制弹性生态空间内部地类的用途转变, 能发挥自然生态空间的多重效益 ${ }^{[18]}$ 。

自然地理、社会经济、土地利用变更等因子共同影响自然生态空间的物质循环、能量流动、生物迁移等关 键生态过程 ${ }^{[19]}$, 以往针对环境的 “症状管理” 方式不足以解决自然生态空间的整体性与复合性问题。生态空 间结构既影响土地资源的高效配置, 又与社会经济的健康发展有着间接的关联 ${ }^{[20]}$ 。自然生态空间的管制不 再是单纯的城市规划或生态学科的任务, 需人文-经济地理等多学科的介人, 重点加强以社会经济、健康公平 为主的生态-社会耦合关系的研究,综合运用空间管制规则, 以提升自然生态空间管控效力。

因此本研究以高度城镇化的粤港澳大湾区为例,剖析其自然生态空间的总体特征与主要城市管制特色, 指出在城镇化影响下湾区生态空间管控过程中存在的生态保护和社会经济问题,探究大湾区自然生态空间管 控的目标、层次、手段、部门、主体层面的转变方向, 并针对性地提出综合管控的具体建议, 以推动粤港澳大湾 区生态空间管制规则的精准落地和生态管控能力的提升。 
表 1 自然生态空间管控理论研究内容

Table 1 Research content of natural ecological space management and control theory

\begin{tabular}{|c|c|c|c|}
\hline 管控原则 & 管控要素 & 管控内容 & 管控方法 \\
\hline Control principles & Control elements & Control content & Control methods \\
\hline $\begin{array}{l}\text { 全覆盖、差异化、协调性、多功 } \\
\text { 能、连通性、多尺度、多样性和认 } \\
\text { 同感 }\end{array}$ & $\begin{array}{l}\text { 自然保护区、森林公园、湿地、水 } \\
\text { 源保护区、郊野地区等 }\end{array}$ & $\begin{array}{l}\text { 土地利用、生态系统服务功能、 } \\
\text { 公平性、健康、生态产品质量等 }\end{array}$ & $\begin{array}{l}\text { 3S 技术、数学模型等实证主义方 } \\
\text { 法、社会网络分析等人本主义方法 }\end{array}$ \\
\hline
\end{tabular}

\section{1 研究区概况}

粤港澳大湾区总面积约 5.6 万 $\mathrm{km}^{2}$,东北和西北地 区以山地为主,平原集中在中部及其他沿海地区,整体 呈现北高南低的地势 (图 1)。高速城镇化影响下大湾 区的建成环境与自然生态环境的空间均衡逐渐被打破， 各种生态危机风险明显增加 ${ }^{[21]}$,迫切需要从单一的土 地用途管制走向社会-经济-生态交互的综合管控,以维 护湾区安全健康的发展。

\section{1 生态特征}

粤港澳大湾区生态要素繁多,包含山水林田湖草等 多类型国土资源及多种多样的生物资源 ${ }^{[22]}$ 。其中, 江 门、珠海、惠州等地海洋资源丰富,肇庆、惠州等地森林 资源充沛,港澳地区自然保护区与城市公园等绿地资源

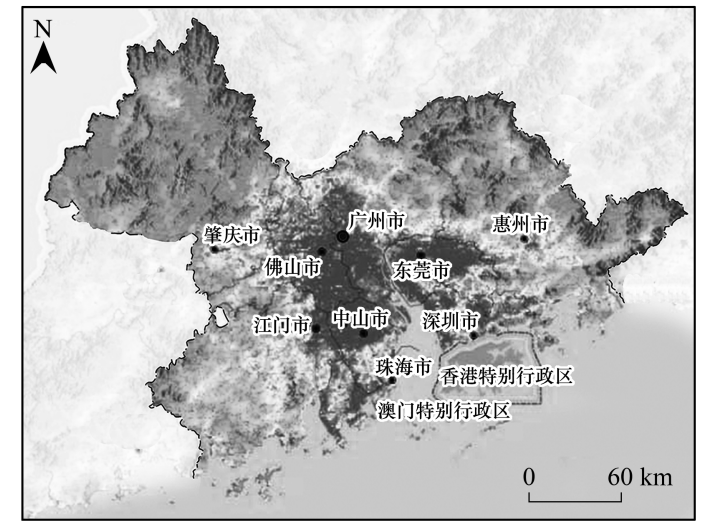

图 1 粤港澳大湾区区位图

Fig.1 Location Map of Guangdong-Hong Kong-Macao Greater Bay Area

体系成熟, 南海有典型的海草床、珊瑚礁等自然生态要素。湾区各城市根据辖区内不同的生态要素主体, 结合 城市发展特征,构建了多样化的自然生态空间格局。如澳门半岛开发趋于饱和,生态空间破碎化程度较高,林 地、山体、水体等大面积自然生境主要存在于离岛区域 ${ }^{[20]}$ 。佛山地势西高东低,在广佛一体化建设的影响下, 提供生态服务功能的生态空间呈现出 “西多东少” 的空间格局特征 ${ }^{[23]}$ 。东莞为推动自然生态空间高质量发 展, 将森林、湿地等生态要素融人市民生活, 塑造了“半城山色半城水”的生态空间格局。

\section{2 社会特征}

大湾区在两种社会体制下形成多元化的生态空间治理方案。根据国家国土空间规划改革实行大部制的 要求,广东省各市新组建的自然资源局按照 “纵向到底, 横向到边” 的垂直管理体系管控生态用地 ${ }^{[24]}$; 港、澳 地区因历史原因,生态空间的治理受到国外绿色规划的直接影响, 将景观生物保护和教育康乐统筹, 注重立 法,针对不同功能分区制定法规条例形成政策管控合力 ${ }^{[25]}$, 在行政上对应功能分区各部门实行平行管理,如 香港郊野公园由渔农署划定,城市规划委员会确定特殊科学价值地区等。

\section{3 经济特征}

大湾区市际间的行政边界多处在河道、山体等自然生态空间中,不同城市、不同部门对生态空间保护、利 用与管控具有不同的态度与着重点。生态空间保护的责任、实施、监督等部门权属存在着跨市、跨部门的交叉 性。政府部门、开发商、市民等对生态空间保护与发展的需求,与自然生态空间的承载能力存在经济利益、保 护管控、休闲娱乐等多方面的复杂矛盾 ${ }^{[26]}$ 。

\section{4 小结}

粤港澳大湾区山、水、城、田、海生态系统类型俱备,植被类型丰富,但现阶段各城市对生态要素的保护、开 发、投人的程度均不同,湾区内自然生态空间不断受到挤压, 平均土地开发强度已超过 $30 \%$ 的国际警戒标准， 城镇建设空间与自然生态空间逐渐失衡 ${ }^{[27]}$ 。针对粤港澳地区自然生态空间丰富的生态要素、多样的生态格 局、多元的管制体制、复杂的发展利益等生态-社会-经济特征, 从资源利用管理和从生态保护需求出发, 对湾 
区自然生态空间进行综合管控,有利于实现湾区对自然资源的所有权和控制权,减少资源开发利用过程中的 负面影响。同时,作为我国国土空间规划改革先行先试地区, 粤港澳大湾区迫切需要从湾区国土空间管控的 实际需求出发, 以问题导向和目标导向为指引,探索如何在保证城镇发展的同时通过提升生态管控能力落实 自然生态空间保护, 以支撑湾区生态文明的高质量发展。

\section{2 粤港澳大湾区主要城市自然生态空间管控模式分析}

粤港澳大湾区的区域生态系统服务功能属于《全国生态功能区划》划分的人居保障功能大类中的大都市 群生态功能类型,生态保护与管控的主要方向是控制城市规模, 加强生态城市建设。湾区城市根据各自的城 市发展状况和自然生态空间结构特征,进行了不同的生态空间用途管制实践探索。

\section{1 广东省}

我国广东省实行 “三线一单” 的管控模式 ${ }^{[28]}$, 即对生态保护红线、环境质量底线、资源利用上线和生态环 境准人清单进行精细化管理。从分类管理角度出发,梳理国土局等相关部门的各类生态要素,构建生态保育 型、休闲游憩型、安全防护型、垦殖生产型 4 大分区类型及 28 小类的生态要素数据库 (图 2), 并融人各市域 “三线两区” 空间治理体系, 落实生态用地的动态维护 ${ }^{[29]}$ 。

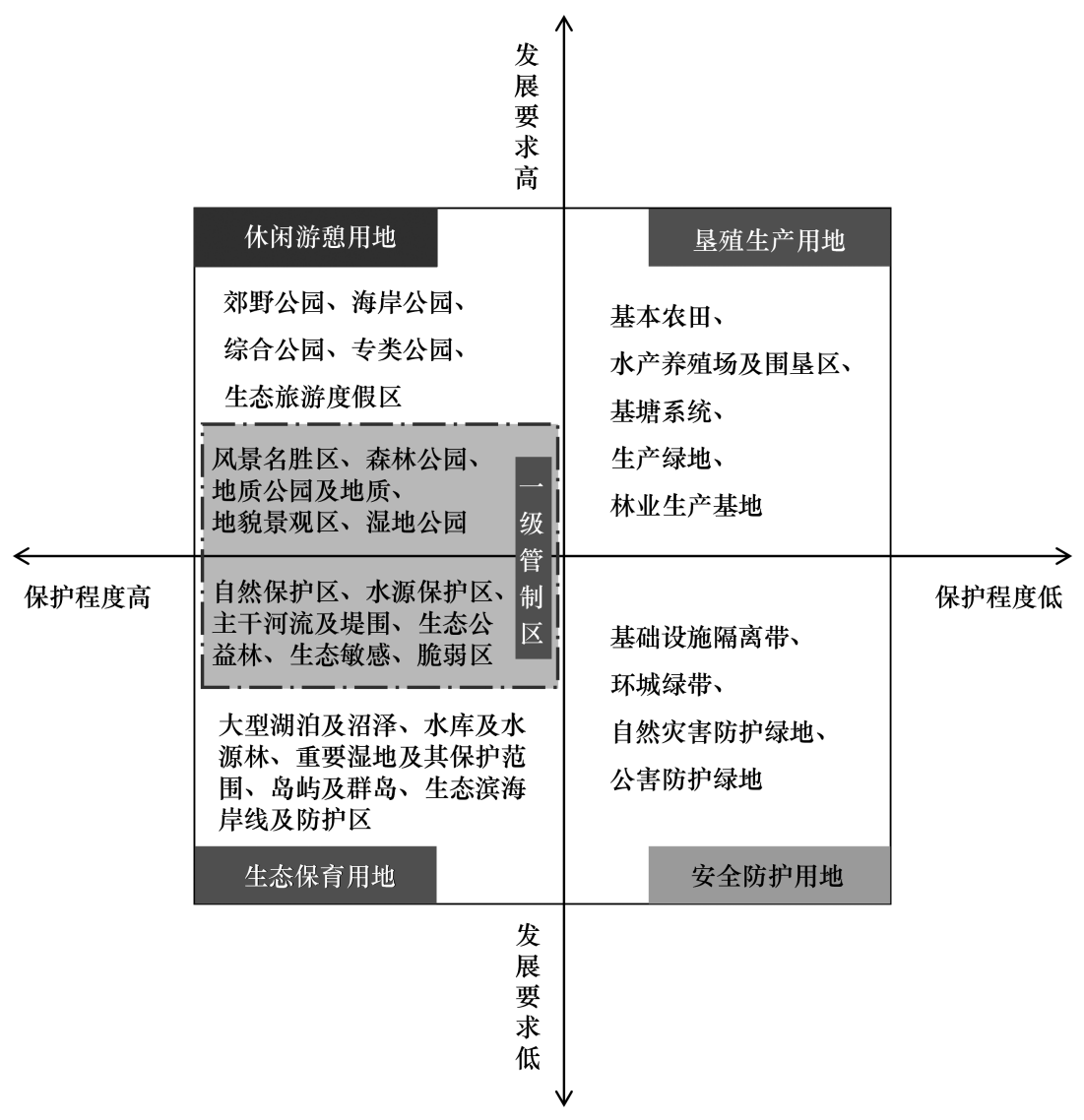

图 2 广东省生态控制类型与生态要素

Fig.2 Ecological Control Types and Ecological Elements in Guangdong Province

在省级管控要求的基础上,各地市结合地方实际情况采取了不尽相同的管控方法。广州以 22 个功能片 区为单位,划分三种类型生态功能单元: (1)城镇开发边界外围的基质类生态单元。以行政村为初步空间单元, 结合生态空间分类方案,划分或归并,形成生态功能单元, 采取 “分区准人+控制指标” 的管控方式,如自然保 护区的控制指标包括生态保护红线面积、生态控制区面积、生境保育指标、水环境与土壤环境质量等。(2)与城 
镇开发边界嵌合的生态功能单元。结合法定政策区边界调整规划管理单元，一个自然保护地作为一个独立的 生态单元, 采用详细规划方式管控。(3)廊道类生态单元。对于河流廊道等起到生态联系功能的重要结构性生 态空间,划定廊道类生态单元, 以详细规划方式管控。控制指标包括: 廊道总面积、廊道宽度、廊道内绿地和非 建设用地比例、廊道内水面率、连通度指数等。深圳在基本生态控制线的基础上划分三级管制区,融合自然环 境、生态资源、土地管理、用地权属等多重要素综合划定生态单元作为基本管理单元,分为各类资源保护区、郊 野公园等,编制生态空间详细规划 ${ }^{[30]}$ 。佛山挖掘自然生态空间的多元服务功能,整合湿地、森林、山脉等自然 生态要素,从“乡一城郊一城区一社区”四个层级构建“域一圈一环一点”四个层次生态生活圈,对自然生态空 间与市民生活共享协同发展进行探索。

\section{2 香港}

我国香港推行国际生态合作公约及协定,赋予生态空间管制的权力,注重生态保护立法,构建了功能分类 明确、责权部门清晰、管控规则精细的生态环境管制体系。政府部门组建专项委员会,制定了针对城市、环境、 公园、动植物等生态环境管控要素的专项管控法规公文与行动准则, 并明确实施监督管理与落实运行的管控 部门职责(图 3)。渔农自然护理署和规划署按照刚性、弹性相结合的原则平行管理生态空间,在保护生态空 间功能环境的基础上进行健康有序的城市发展建设, 如经评估认定对生态环境无影响的道路、污水处理设施 等城市基础设施可获得审批,生态工程项目、休闲游㰾设施等必要的基础设施允许建设。同时,香港积极调动 社会力量参与生态空间的治理,针对生态保育区制定管理协议计划和公私营界别合作计划, 实行政府和社会 的协同管理 ${ }^{[31]}$,通过成立海洋公园公司、环境及自然保育基金等多种形式积极实行生态宣传、普及全民生态 教育,使市民的生态保育意识上升为社会共识。

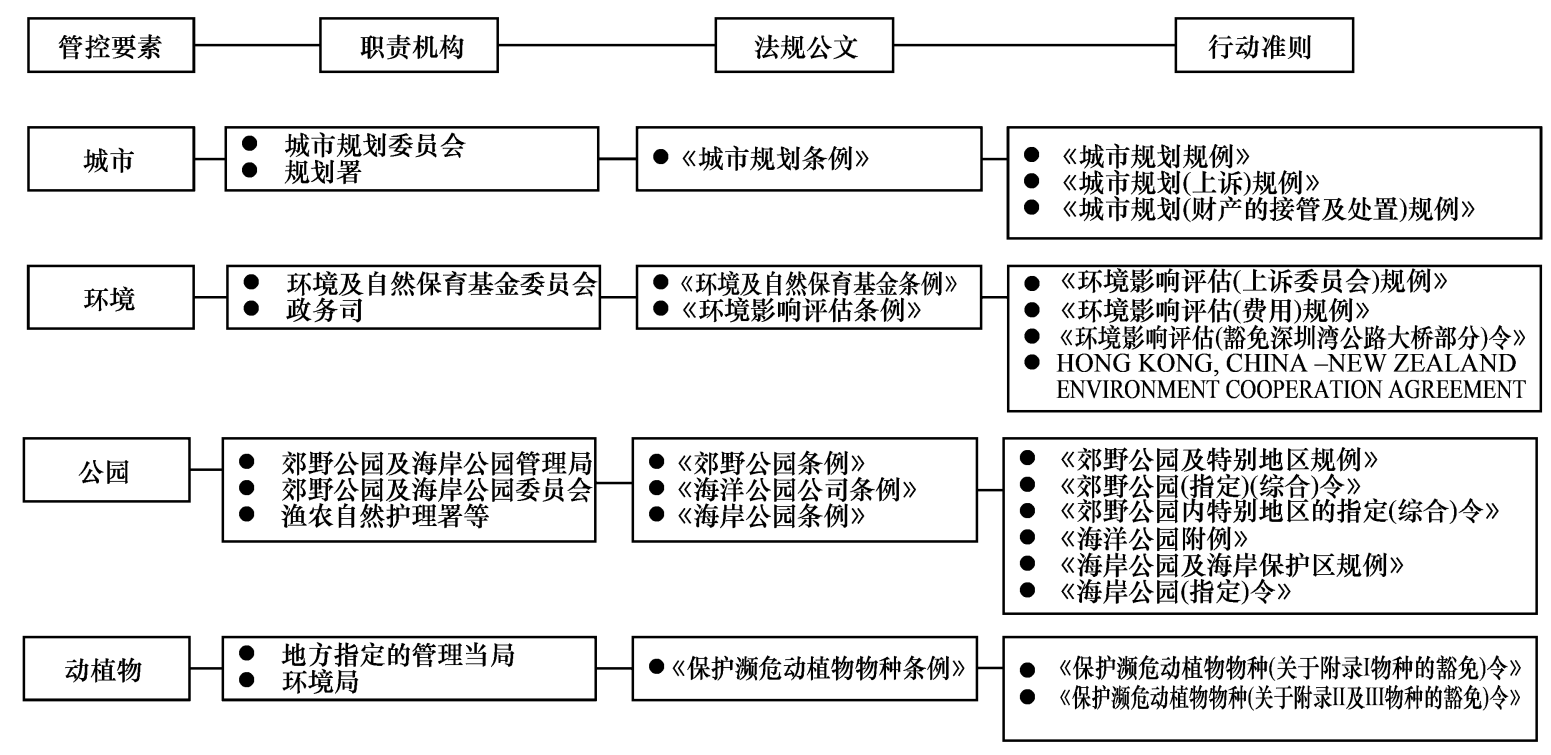

图 3 香港生态空间管控的法制体系

Fig.3 Legal System of Hong Kong Ecological Space Control

2.3 澳门

我国澳门土地总面积为 $32.9 \mathrm{~km}^{2}$,其中半岛地区面积相对狭小,人口集中, 自然生态系统主要以海洋和大 量小面积的休㮩游览绿地为主; 离岛地区面积较大,生态保护区和郊野公园占比较多,呈现出 “大疏大密” 的 生态空间结构。澳门环境保护局发布的《澳门环境保护规划 (2010-2020)》提出采用环境功能区划管理的方 式,将全澳划分为环境严格保护区、环境引导开发区以及环境优化控制区三大类:(1)环境严格保护区以维护珍 贵的生态资源为主, 严禁一切与生态保护和修复无关的建设项目; 2 环境引导开发区根据澳门特有城市结构 分为一类区和二类区, 以生态保育为主, 在环境管理指引或标准的指导下可进行有限制的开发利用; (3)环境优 
化控制区以改善生态质量和功能为主,管控限制较弱,可进行适度的开发利用 ${ }^{[32-34]}$ (表 2)。

表 2 澳门综合环境功能区划分区

Table 2 Macao Integrated Environmental Function Zone Division

\begin{tabular}{|c|c|c|}
\hline $\begin{array}{l}\text { 功能分区 } \\
\text { Functional division }\end{array}$ & $\begin{array}{l}\text { 范围 } \\
\text { Range }\end{array}$ & $\begin{array}{l}\text { 管理策略 } \\
\text { Management strategy }\end{array}$ \\
\hline $\begin{array}{l}\text { 环境严格保护区 } \\
\text { Strict environmental protection zone }\end{array}$ & $\begin{array}{l}\text { 主要包括澳门所有的水塘、湖 } \\
\text { 泊、山体和世遗历史城区 }\end{array}$ & $\begin{array}{l}\text { 属生态敏感性较高的区域,生态环境脆弱, 极易受到破坏, 且一 } \\
\text { 旦破坏后很难修复,必须严格保护和控制建设 } \\
\text { 合理控制土地开发的规模和强度, 对林地与水体等自然资源的 } \\
\text { 开发利用要以不损害生态系统为原则 } \\
\text { 尽量避免一切导致生态功能退化的开发活动和其他人为破坏 } \\
\text { 活动,采用严格的保护手段及污染控制措施 }\end{array}$ \\
\hline $\begin{array}{l}\text { 环境引导开发区 } \\
\text { Environmental guidance } \\
\text { development zone }\end{array}$ & $\begin{array}{l}\text { 主要包含新城填海区、函仔、路 } \\
\text { 函新城和路环岛区域(其中环境 } \\
\text { 严格保护区和环境优化控制区 } \\
\text { 的部分除外) } \\
\text { 主要为澳门半岛区域 (环境严格 } \\
\text { 保护区的部分除外) }\end{array}$ & $\begin{array}{l}\text { 是生态敏感性处于中等的区域, 可以作为引导发展区或过渡 } \\
\text { 区,宜在指导下进行有限制的开发利用,并适当控制城市建设 } \\
\text { 用地的开发 } \\
\text { 对旧城区的开发要逐步改造,进行有限制性的开发 } \\
\text { 严格控制新城区和填海区开发的强度,合理规划城市布局 } \\
\text { 在开发建设的同时辅以城区生态绿化,保护城市的景观风貌, } \\
\text { 保护各种自然景观要素和人文要素 }\end{array}$ \\
\hline $\begin{array}{l}\text { 环境优化控制区 } \\
\text { Environmental optimization control area }\end{array}$ & $\begin{array}{l}\text { 主要分布在澳门机场、临海工业 } \\
\text { 区、九澳电厂、九澳水泥厂、九澳 } \\
\text { 油库 }\end{array}$ & $\begin{array}{l}\text { 可作适度开发利用,但必须保证开发利用不会导致环境质量的 } \\
\text { 下降的地区 } \\
\text { 区内设施相对污染较大,必须严格控制污染 } \\
\text { 应透过优化区内产业布局及结构调整和工业污染源治理, 限制 } \\
\text { 严重污染环境的行业和企业,防止污染扩大化 }\end{array}$ \\
\hline
\end{tabular}

来自:《澳门环境保护规划 $(2010-2020) 》$

\section{3 粤港澳大湾区自然生态空间管控存在的问题与分析}

粤港澳大湾区整体自然生态空间特征复杂,各地市现行的生态空间管控模式多样,普遍存在着生态保护 与社会发展之间的矛盾,各自的特色与优势在区域层面还未得到充分体现。

3.1 自然生态空间建设活动指引粗放,生态服务功能价值降低

以往城市建设用地是城乡规划和管制的重点, 缺少市、县总体范围内对于生态、农业、城镇空间的统筹, 针 对生态安全的建设活动管控政策供给不足。城镇建设用地碎片化分布、村庄建设用地与农田交织凌乱、城市

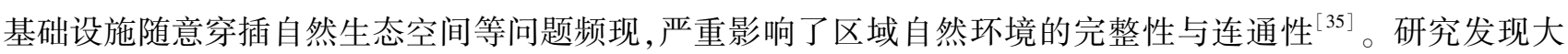
湾区的土壤保持与生态环境质量的服务水平呈现出东西部高、中部低的空间分布格局,生态服务功能表现出 较强的空间异质性 ${ }^{[36]}$ 。经测算粤港澳大湾区固碳释氧量发现, $91.57 \%$ 的固碳释氧价值损失主要是由城镇建 设用地侵占农田和草地空间引起的 ${ }^{[37]}$ 。有学者应用多种模型预测未来十年广东省城镇化发展的空间格局得 出, 到 2030 年将以年均 $6.28 \%$ 的增长率新增 $3407 \mathrm{~km}^{2}$ 的城镇化土地 ${ }^{[38]}$, 扩张需求的建设空间与自然生态空 间保护持续博弯,自然生态空间的生态产品和生态服务的内涵式保护利用面临较大威胁。

3.2 生态空间分类标准不统一,生态用地利用效率较低

现行空间性规划对具有巨大生态价值的未利用土地和城镇周边的山体、水体、郊野公园等用地归类缺乏 明确规定 ${ }^{[39]}$, 因此, 大湾区各城市对区域内自然生态空间采用不同的管控标准和约束底线,形成了差异化的 空间分类体系。特别是从功能角度, 自然生态用地缺乏明确的概念界定和详细的功能分类,生态性空间与建 设性空间在一定程度上界线不清, 城镇建设区内一些禁止或限制建设的空间没有体现为生态用地空间 ${ }^{[40]}$, 导 致区域内自然生态空间的覆盖不足, 大量自然生境被人工改造为城市生境, 耕地质量整体退化, 海洋特色生态 系统和渔业资源衰退, 具有独特生态价值的湿地被转换为单一功能的农用地或建设用地。如深圳在人为改造 的生态用地侵占下, 所拥有的高质量自然森林面积已低于生态控制线面积的 $1 / 3^{[41]}$, 导致生物种类减少, 生态 空间活力下降。澳门自然生产力已低于 $1^{[42]}$, 表明自然生态空间土地利用效率低下, 其土地利用的生物生产 
力低于全球各类土地利用的平均生产力。

3.3 空间管控事权分离, 生态管控合力不足

粤港澳三地对自然生态空间保护和开发的管控具有不同的行政主体。香港由环保署、警方等多部门协同 参与生态环境监管, 环保署下属的办事处是贯彻执行环保法律法规执法活动的主要负责方。澳门环保局是统 一管控自然生态空间的防治、控制、处理环境污染制度的行为主体，通过立法执法对生态空间环境进行规制。 广东省在国家颁布的大气、水、土壤等生态环境要素保护的法律法规的指引下,因地制宜制定了地方性的环境 管理政策和标准 ${ }^{[43]}$, 在自然资源部组建之前我国没有空间规划来统筹社会、经济、环境的协调发展, 因此环境 规划与城市规划在无强制性协调控制的因素下,按照各自的规划体系编制专项规划, 导致环境规划和城市规 划无法协调,很难对生态空间保护与城市发展建设进行有效的指导和精确的管控。因此,大湾区自然生态空 间在不同规划中出现的生态环境相关空间的内容均有不同程度的边界重叠, 这给生态空间的利益协调带来很 大的难度和不确定性 (表 3), 未能形成管控合力 ${ }^{[44]}$ 。

表 3 各类规划中与生态相关的分区比较

Table 3 Comparison of ecologically relevant zones in various plans

\begin{tabular}{ll}
\hline 规划类型 Planning type & 与生态相关的分区 Eco-related zoning \\
\hline 土地规划 Land planning & 禁止开发区,基本农田集中区,生态环境安全控制区,自然与文化遗产保护区 \\
& 禁止开发区,农业用地,生态用地, 风景名胜区,湿地、水源保护区等生态敏感区,地下矿产资 \\
城市规划 City planning & 源分布地区,绿地系统等 \\
& 水源涵养生态功能区,土壤保持生态功能区, 防风固沙生态功能区,生物多样性保护生态功能 \\
生态功能区划 & 区,洪水调蓄生态功能区,林产品提供生态功能区 \\
Ecological function zoning &
\end{tabular}

3.4 生态建设与社会发展不匹配,共享参与机制尚未完善

在当前促进经济高速发展的市场力主导下,生态用地由非建设用地向建设用地转化多呈现出经济效益推 动的市场化行为; 而只有当土地的生态价值面临严重威胁时,体现规划控制的政府力才有可能强制将建设用 地转化为非建设用地, 这与大湾区城市群高质量发展阶段中人民日益增长的生态需求不匹配。虽然粤港澳三 地拥有山水林田湖草等丰富的生态要素, 但粗放的城镇开发建设往往忽视自然生态空间的有效管护, 导致城 镇与生态分离, 难以充分发挥建设用地与非建设用地在空间上生态-经济-社会的综合效益 ${ }^{[45-46]}$ 。目前, 大湾 区范围内自然生态空间的用地权属、景观布局和环境保护等相关权益尚未在法律法规和现实中得到表现和落 实,生态保护难以形成有意识的行为。特别是相对于港澳而言, 内地自然生态空间管控的执行和监管由各级 环保部门进行, 主要依靠行政力量, 公众参与度相对较低,生态意识的积极性普遍较低。

\section{4 讨论与建议}

粤港澳大湾区自然生态空间管控过程中出现的一系列问题,严重影响新时代大湾区生态文明建设。《粤 港澳大湾区发展规划纲要》提出以绿色发展、保护生态为原则, 以建设生态安全、环境优美的美丽湾区为引 领, 到 2035 年实现宜居宜业宜游的生态型湾区。在自然生态空间管控领域, 应从自然生态空间管控的目标、 层次、手段、部门、主体等角度进一步增强区域发展的协调性，逐渐向技术与政策结合、顶层与底层共同设计、 宏观发展规划与具体行动计划同步实施的综合管控转变。

4.1 从增长导向转向生态导向, 提升湾区整体生态服务功能

从管控目标上来看, 应转变以增长为导向的无序扩张思路,加强自然生态空间功能价值提升的整体性保 护。识别与统筹自然生态要素, 建立湾区全域全要素的生态系统数据库, 作为生态保护与城市发展建设协调 的基础资料。通过 InVEST 等模型模拟不同土地覆被情景下生态服务系统的功能变化,针对性开展生态环境 承载力、生态服务功能、生态敏感性等生态系统服务价值的定量评价, 为政府部门的决策提供科学依据。协调 “深港” 和 “江肇广惠” 跨区域的山林屏障带建设, 提升连片山地丘陵的连通性。强化湾区南部的海洋资源及 
海岸线保护, 提升连续的近岸海域生态系统完整性。严格控制建成区扩展,优先将生态空间规划作为用途管 制的基础,赋予用途管制新的内涵,强化生态空间土地开发的集约利用和生态要素的保护性要求。重视自然 保育,以珠海、江门、惠州、广州为重点城市,开展林地、草地、滩涂、浅海区等生态建设和恢复保育工作; 香港、 澳门注重设置市内公园、郊野公园等自然保育区域, 全面促进生物承载力提升, 满足区域生态服务公共产品的 供给。

4.2 从单一城镇尺度转向“区域-市县-单元”多维尺度,优化分级分类空间模式

从管控层次上来看,应转变湾区各市基于单一城镇尺度的生态空间格局塑造,注重“区域-市县-单元”多 维尺度的空间分类衔接和细化。区域层面定结构、定规模、定边界, 明确自然生态空间边界约束,结合周边用 地功能布局, 明确自然生态空间的主要服务功能。依据生态主导功能和自然保护价值, 形成生态保育型、休闲 游悡型、生态廊道型三种生态功能类型,并对不同类型分区制定相应规划管控机制与实施措施。市县层面生 态空间功能分类多元化, 划分功能区块, 确定用地类型与比例, 制定准人项目类型正负面清单和重要要素控制 指标。实行分级动态管控,生态底线区执行最严格的生态保护制度,生态发展区在确保生态资源不受破坏的 前提下, 严格按照项目准人条件及相关建设要求, 有限制地进行管控。通过协调行政边界、规划管理边界落实 精细化的分类管控需求。单元层面生态空间功能更加细致,划定单元边界落实地块的具体建设项目指标。每 种生态功能类型的单元应充分考虑现状建设以及发展需求, 与相关规划进行充分协调, 与生态控制线等管理 边界进行衔接, 确保生态空间管制要求可落地实施(图 4)。

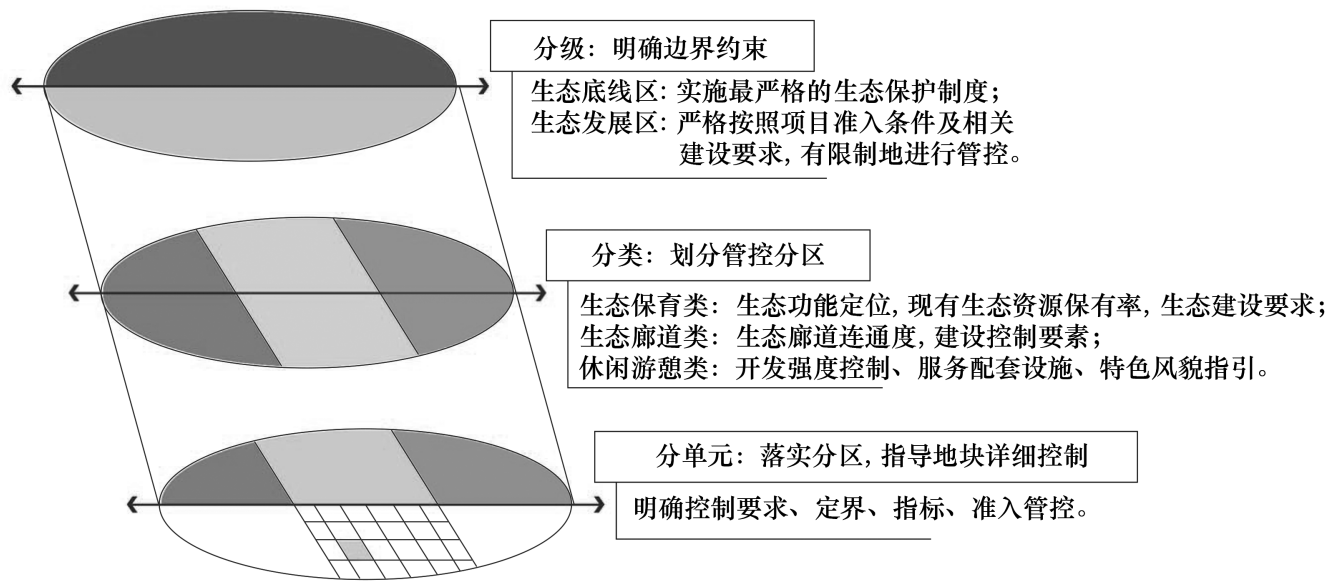

图 4 分级分类管控图

Fig. 4 Classification and control chart

4.3 从静态控制转向动态管控, 建立控引结合的弹性指标体系

从管控手段上来看,简单划定城市增长的刚性界限往往事倍功半, 城市增长边界的划定应考虑市县的发 展需求, 预留弹性增长空间, 确保自然生态空间内生态保护与保护性利用并重, 提升生态用地的利用效率。在 生态空间分级分类的基础上,建立禁止准人建设项目的清单管理机制,提出刚性和弹性相结合、绿色低碳导向 的整体性控制引导指标体系。从整体规定、建设用地规定、非建设用地规定、综合利用引导四个方面提出相应 的指标, 明确主导功能、量控、线控、项目准人、景观指引等规划管控要求, 通过法定规划落实, 指导各生态单元 控规和建设实施方案编制, 实现生态空间管控的法定化, 适应社会经济发展的新形势。根据管控单元的主体 功能定位、规划主要产业导向以及存在的问题,政府应对影响城乡生态安全格局的单元制定详细管理要求, 对 建设项目提出建设指引以约束空间布局, 控制污染排放, 提高资源利用效率。因地制宜细化和调整管理要求, 以改善单元内的生态环境问题,达到设定的生态环境质量目标(表 4)。 
表 4 管控指标及准入要求

Table 4 Control indicators and access requirements

\begin{tabular}{|c|c|c|c|c|c|c|c|c|}
\hline \multirow{2}{*}{$\begin{array}{l}\text { 类别 } \\
\text { Category }\end{array}$} & \multicolumn{4}{|c|}{$\begin{array}{l}\text { 指标体系 } \\
\text { Index system }\end{array}$} & \multicolumn{4}{|c|}{$\begin{array}{c}\text { 管控措施/建设指引 } \\
\text { Control measures/Construction guidelines }\end{array}$} \\
\hline & $\begin{array}{l}\text { 整体规定 } \\
\text { 指标 }\end{array}$ & $\begin{array}{l}\text { 建设用地 } \\
\text { 规定指标 }\end{array}$ & $\begin{array}{l}\text { 非建设用 } \\
\text { 地规定指标 }\end{array}$ & $\begin{array}{l}\text { 综合利用 } \\
\text { 引导指标 }\end{array}$ & $\begin{array}{l}\text { 空间布局 } \\
\text { 约束 }\end{array}$ & $\begin{array}{l}\text { 污染物排 } \\
\text { 放管控 }\end{array}$ & $\begin{array}{l}\text { 环境风险 } \\
\text { 防控 }\end{array}$ & $\begin{array}{l}\text { 资源利用 } \\
\text { 效率 }\end{array}$ \\
\hline $\begin{array}{l}\text { 生态保育单元 } \\
\text { Ecological } \\
\text { conservation unit }\end{array}$ & $\begin{array}{l}\text { 人口容量、建 } \\
\text { 设用地比例、 } \\
\text { 生态用地比 } \\
\text { 例、开发强度 }\end{array}$ & $\begin{array}{l}\text { 用地面积、准 } \\
\text { 人用地类型 }\end{array}$ & $\begin{array}{l}\text { 山体禁建线、 } \\
\text { 水面率、林地 } \\
\text { 面积 }\end{array}$ & $\begin{array}{l}\text { 产业 发 展 } \\
\text { 方向 }\end{array}$ & $\begin{array}{l}\text { 禁止或限制 } \\
\text { 的开发建设 } \\
\text { 活动、不符合 } \\
\text { 空间布局要 } \\
\text { 求活动退出 } \\
\text { 方案 }\end{array}$ & $\begin{array}{l}\text { 现有源提标 } \\
\text { 改造、新增源 } \\
\text { 等量或倍量 } \\
\text { 替代、新增源 } \\
\text { 排放标准限 } \\
\text { 制、污染物排 } \\
\text { 放绩效水平 } \\
\text { 准人等 }\end{array}$ & $\begin{array}{l}\text { 用地、园区及 } \\
\text { 企业环境风 } \\
\text { 险防控等 }\end{array}$ & $\begin{array}{l}\text { 水资源利用效 } \\
\text { 率、地下水禁采 } \\
\text { 或限采、能源效 } \\
\text { 率要求、禁燃 } \\
\text { 区等 }\end{array}$ \\
\hline $\begin{array}{l}\text { 生态廊道单元 } \\
\text { Ecological corridor unit }\end{array}$ & $\begin{array}{l}\text { 人口容量、建 } \\
\text { 设用地比例、 } \\
\text { 生态用地比 } \\
\text { 例、开发强度 }\end{array}$ & $\begin{array}{l}\text { 准人产业门 } \\
\text { 类、容积率、 } \\
\text { 建筑密度、建 } \\
\text { 筑限高 }\end{array}$ & $\begin{array}{l}\text { 山体禁建线、 } \\
\text { 水面率、林地 } \\
\text { 面积、生态廊 } \\
\text { 道面积 }\end{array}$ & $\begin{array}{l}\text { 用地兼容性、 } \\
\text { 产业发展方 } \\
\text { 向、配套设施 } \\
\text { 建设、奖励强 } \\
\text { 度、绿色能源 } \\
\text { 使 用比 例、 } \\
\text { 3R 建筑材料 } \\
\text { 使用率 }\end{array}$ & 同上 & $\begin{array}{l}\text { 区域水及大 } \\
\text { 气污染物允 } \\
\text { 排量、现有源 } \\
\text { 提标改造 }\end{array}$ & $\begin{array}{l}\text { 区域环境风 } \\
\text { 险 联 防 联 } \\
\text { 控等 }\end{array}$ & $\begin{array}{l}\text { 区域水资源总 } \\
\text { 量、地下水禁采 } \\
\text { 或限采、能源总 } \\
\text { 量及效率要求、 } \\
\text { 禁燃区等 }\end{array}$ \\
\hline $\begin{array}{l}\text { 休闲游㮩单元 } \\
\text { Recreation unit }\end{array}$ & $\begin{array}{l}\text { 人口与游客 } \\
\text { 容量、建设用 } \\
\text { 地比例、生态 } \\
\text { 用地比例、旅 } \\
\text { 游设施用地 } \\
\text { 比例、开发 } \\
\text { 强度 }\end{array}$ & $\begin{array}{l}\text { 准人产业门 } \\
\text { 类、容积率、 } \\
\text { 建筑密度、建 } \\
\text { 筑限高 }\end{array}$ & $\begin{array}{l}\text { 山体禁建线、 } \\
\text { 水面率、林地 } \\
\text { 面积 }\end{array}$ & $\begin{array}{l}\text { 用地兼容性、 } \\
\text { 产业发展方 } \\
\text { 向、配套设施 } \\
\text { 建 设、奖 励 } \\
\text { 强度 }\end{array}$ & $\begin{array}{l}\text { 允许、禁止或 } \\
\text { 限制的开发 } \\
\text { 建设活动,不 } \\
\text { 符合空间布 } \\
\text { 局活动退出 } \\
\text { 方案等 }\end{array}$ & $\begin{array}{l}\text { 根据其各类环 } \\
\text { 现状等单元特 } \\
\text { 单元显影部分 }\end{array}$ & $\begin{array}{l}\text { 竟要素属性、单 } \\
\mathrm{E}, \text { 参照优先保 } \\
\text { 人四个方面提出 }\end{array}$ & $\begin{array}{l}\text { 发展定位及发展 } \\
\text { 单元或重点管控 } \\
\text { 求 }\end{array}$ \\
\hline
\end{tabular}

4.4 从事权分离转向协同联动,形成生态空间管控合力

从管控部门上来看,扭转由于行政边界分割导致的自然生态空间管控事权分离,应在达成共识的基础上, 制定关于大湾区自然生态空间用途管制的专项条文,明确湾区自然生态空间管控的目标、原则、主体、方式、程 序及实施保障等,统一指导湾区自然生态空间的保护和利用。同时, 以自然资源部为主导, 成立区域联合体对 湾区的生态环境进行协调与管理,如成立港澳-广佛深生态协会、深圳-惠州组团的珠东管理平台、中山-珠海江门组团的珠西管理平台、肇庆生态委员会等。对具有较高价值的生态用地, 区域联合体直接介人,在有条件 的情况下逐步收归国有, 以避免产权不明晰带来管理实施上的难度。在生态资源统一确权登记的基础上,健 全生态补偿、产业发展引导等多重利益协调机制。实施跨学科的技术应用,结合地理学、社会学、土地管理学 等专业技术的协同创新, 对资源、环境、旅游、建设项目等进行多层次的生态评估与管理咨询(图 5)。构建法 律、行政、经济的深度合作网络,做到区域统筹、陆海统筹、城乡统筹、保护与利用统筹,形成生态保护合力。

4.5 从政府规划管制转向多元主体共治,完善共商共建共享机制

从管控主体上来看,应大力推动公众、企业、智库等多主体参与湾区环境管控,完善共商共建共享的机制。 自然生态空间建设不能仅靠单一的规划管制手段,更需要吸收居民、企业界、学术界等领域的参与,生态规划 和政策制定应广泛地征求各方的意见,有效推动行政管制和市场配置的协同共治,加强自然生态空间管制过 程的双向性。借鉴香港的公私营界别合作计划,建立吸引社会资本投人自然生态空间保护的市场化机制,推 行生态修复第三方治理, 满足经济社会发展对自然生态空间的生态产品与服务的多样化需求。

\section{5 总结与展望}

粤港澳大湾区各城市因生态资源禀赋、发展阶段、发展诉求各有差异, 各地自然生态空间的划定方式与管 控方法也呈现出不同特征, 但均遵循建法立制的管控手段, 并通过用地功能分级分类、项目准人清单等途径落 


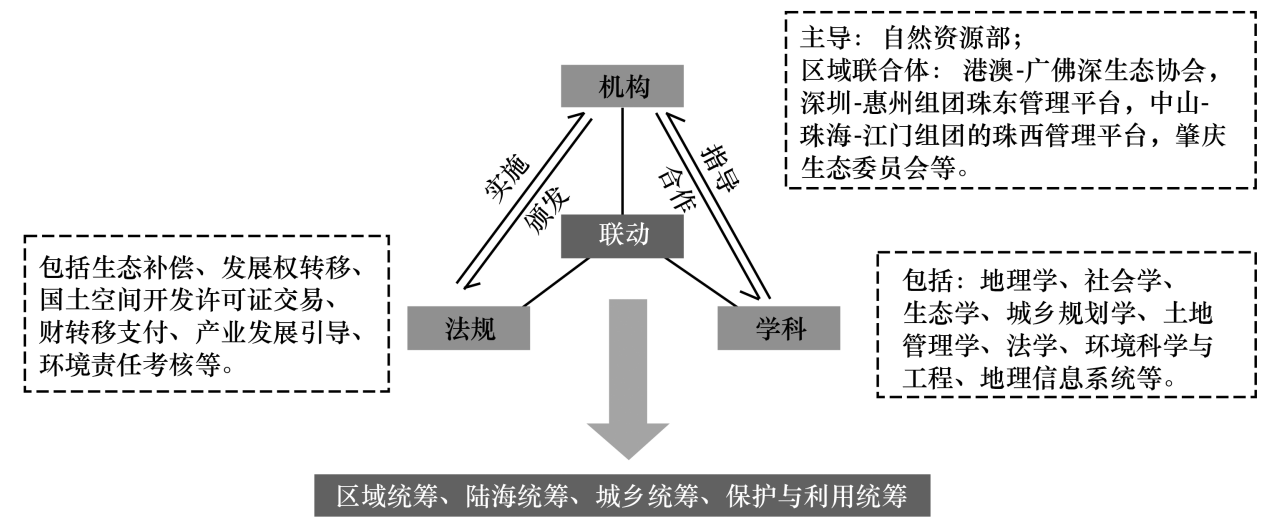

图 5 区域协调联动机制图

Fig.5 Regional coordination linkage mechanism diagram

实生态管控。广东省的“三线一单”和澳门的环境功能区划对土地用途的管控简单明确, “建设用地”与“非建 设用地”针对各类建设项目的准人条件相对明确,对于生态用地的利用与控制有较强的约束作用。从控制内 容和实践情况来看,广东省生态要素及生态分区划分精细,但跨市政府部门间的协作与沟通较少,易导致区域 自然生态要素管控不到位。香港因管理体制的不同,由规划署、渔农署、各种委员会、基金组织等机构共同协 助生态管控与发展资助, 自然生态空间管控事权明确。

湾区各城市的自然生态空间管制更多的是基于自身发展需求的治理,生态空间管控过程中出现了建设活 动指引粗放、空间分类标准不统一、空间管控主体事权分离、共享参与机制不完善等主要问题。为提升粤港澳 大湾区自然生态空间管控成效,综合考虑湾区自然生态空间生态-社会-经济特征, 提出以生态优先为原则, 统 筹区域整体自然生态要素,提升湾区自然生态空间服务功能价值;优化“区域-市县-单元”尺度下分级分类空 间模式,形成“功能类型分类-分区管制指引-单元指标落地” 的分层控制体系; 充分考虑现状建设以及未来发 展需求,建立控引结合的弹性规划指标,指引自然生态空间可持续发展建设;构建大湾区生态空间管控的协调 联动机制,形成生态管控合力 ; 推动多主体参与共治,实现公平与效率的平衡。

自然生态空间综合管控的实质是对城市增长与生态环境保护之间双向耦合的结构功能关系的调理,未来 应从系统观、生命观、特色观、人本观的角度进一步探究自然生态空间与城镇社会的相互作用及影响,均衡配 置建成环境与自然生态环境的用地空间, 明确自然生态空间实施生态修复和用途管制后的产业发展路径, 细 化落实自然生态空间在生态、社会、经济层面的综合管控措施, 以促进自然生态空间综合管控效益的提升。

\section{参考文献 (References) :}

[ 1 ] 张坤, 李恒, 张雅宁, Khamdy L, 周嘉驰. 中国自然生态空间研究的知识图谱分析. 国土资源科技管理, 2020, 37(2) : 14-25.

[ 2 ] 王志金金. 自然生态空间用途管制的法律制度应对. 中国土地科学, 2020, 34(3)：9-15.

[ 3 ] 刘洋. 自然生态空间用途管制的法律问题分析. 中国土地, 2020, (4) : 27-29.

[ 4 ] Dadvand P, Nieuwenhuijsen M. Green space and health//Nieuwenhuijsen M, Khreis H, eds. Integrating Human Health into Urban and Transport Planning. Cham: Springer, 2019: 409-423.

[ 5 ] Ngom R, Gosselin P, Blais C. Reduction of disparities in access to green spaces: their geographic insertion and recreational functions matter. Applied Geography, 2016, 66: 35-51.

[ 6 ] Curran W, Hamilton T. Just green enough: contesting environmental gentrification in Greenpoint, Brooklyn. Local Environment, 2012, 17(9): 1027-1042.

[ 7 ] Bolliger J, Silbernagel J. Contribution of connectivity assessments to green infrastructure (GI). International Journal of Geo-Information, 2020, 9 (4) : 212 .

[ 8 ] Mell I C. Green infrastructure: reflections on past, present and future praxis. Landscape Research, 2017, 42(2) : 135-145.

[ 9 ] Jerome G. Defining community-scale green infrastructure. Landscape Research, 2017, 42(2): 223-229. 
[10] Grădinaru S R, Hersperger A M. Green infrastructure in strategic spatial plans: evidence from European urban regions. Urban Forestry \& Urban Greening, 2019, 40: 17-28.

[11] Benton-Short L, Keeley M, Rowland J. Green infrastructure, green space, and sustainable urbanism: geography's important role. Urban Geography, 2019, 40(3) : 330-351.

[12] Horwood K. Green infrastructure: reconciling urban green space and regional economic development: lessons learnt from experience in England's north-west region. Local Environment, 2011, 16(10): 963-975.

［13］赵艈芳，祁帆，邓红蒂. 生态空间用途管制的八大特征变化. 中国土地，2019，(5): 12-15.

[14] 祁帆, 李宪文, 刘康. 自然生态空间用途管制制度研究. 中国土地, 2016, (12) : 21-23.

[15] 黄征学, 蒋仁开, 吴九兴. 国土空间用途管制的演进历程、发展趋势与政策创新. 中国土地科学, 2019, 33(6)：1-9.

[16] 曹宇, 王嘉怡, 李国煜. 国土空间生态修复: 概念思辨与理论认知. 中国土地科学, 2019, 33(7): 1-10.

[17］叶定超, 许倍慎. 三峡生态经济合作区区域生态空间格局研究. 农家参谋, 2019, (1)：192-192, 265-265.

[18］李云，程欢，于海波. 基于“分区管制”的自然生态空间用途管制研究. 资源信息与工程, 2019, 34(1)：106-108.

[19] 蔡云楠, 肖荣波, 艾勇军, 李晓晖. 城市生态用地评价与规划. 北京: 科学出版社, 2014: 16-19.

[20] 孟楠, 韩宝龙, 王海洋, 逯非, 许超, 欧阳志云. 澳门城市生态系统格局变化研究. 生态学报, 2018, 38(18)：6442-6451.

[21] 甘琳, 陈颖彪, 吴志峰, 千庆兰, 郑子豪. 近 20 年粤港澳大湾区生态敏感性变化. 生态学杂志, 2018, 37( 8) : 2453-2462.

[22] 翟紫含, 张杰, 周旭. 粤港澳大湾区山水林田湖草生态保护修复相关问题思考. 中国土地, 2020, (12) : 26-29.

[23] 钟亮, 林媚珍, 周汝波. 基于 InVEST 模型的佛山市生态系统服务空间格局分析. 生态科学, 2020, 39(5)：16-25.

[24] 余云州, 王朝宇, 陈川. 新时代省级国土空间规划的特性与构建一一基于广东省的实践探索. 城市规划，2020，44(11)：23-29，37-37.

[25] 李丹. 奥港澳大湾区湿地保护的协同治理法制化一以生态系统功能和服务的提升为目标. 华南师范大学学报: 社会科学版, 2020 , (2) : 140-152.

[26] 陈长虹, 刘颂. 基于多元利益主体行为和权益的生态保护红线实施与管理策略. 上海城市规划, 2020，(1)：29-33.

[27] 王文静, 韩宝龙, 郑华, 欧阳志云. 粤港澳大湾区生态系统格局变化与模拟. 生态学报, 2020, 40(10): 3364-3374.

[28］万军, 秦昌波, 于雷, 吕红迪. 关于加快建立“三线一单”的构想与建议. 环境保护, 2017, 45(20)：7-9.

[29］何冬华. 生态空间的“多规融合”思维：邻避、博弯与共赢一一对广州生态控制线“图”与 “则”的思考. 规划师, 2017, 33(8)：57-63.

[30］戴晴, 唐豪. 高度城市化地区生态空间管理的实践与探索——以深圳为例. 上海城市规划, 2018, 1(3): 13-16.

[31］夏欢，杨耀森. 香港生态空间用途管制经验及启示. 中国国土资源经济, 2018, 31(7): 62-65.

[32] 耿宏兵, 袁壮兵. 资源稀缺条件下的澳门绿色生态环境改善策略研究. 国际城市规划, 2011, 26(5): 98-104.

[33] 肖希, 李敏. 绿斑密度: 高密度城市绿地规划布局适用指标研究——以澳门半岛为例. 中国园林, 2017, 33(7): 97-102.

[34] 余美萱, 李敏. 高密度城市绿色空间拓展途径研究——以澳门为例. 福建林业科技, 2014, 41(3): 161-166.

[35] 郑晓华，林小虎，沈洁. “三线合一”的国土空间规划管控体系——南京空间规划从“划”到“管”的探索. 城乡规划，2019，(3)：17-23.

[36] 周汝波, 林媚珍, 吴卓, 刘汉仪, 钟亮. 基于生态系统服务重要性的奥港澳大湾区生态安全格局构建. 生态经济, 2020, 36(7): 189-196.

[37] 温宥越, 孙强, 燕玉超, 肖敏志, 宋巍巍, 杨剑. 粤港澳大湾区陆地生态系统演变对固碳释氧服务的影响. 生态学报, 2020, 40(23): $8482-8493$

[38] 王琎. 珠江口近岸土地利用/覆盖变化及其环境生态效应研究 [D]. 广州: 中国科学院大学( 中国科学院广州地球化学研究所), 2018: $133-133$.

[39］孔江伟，曾坚，高梦溪. 生态文明视角下国土空间分类体系探讨. 规划师, 2019, 35(23)：60-68.

[40] 褚天骄, 李亚楠. 我国乡村规划用地分类标准研究与展望一一来自《村庄规划用地分类指南》的实践反馈与思考. 规划师, 2017, 33( 6) : 61-66.

[41] 邓金杰, 黄伟坚. 城市生态用地管控: 问题及规划管理建议一一以深圳市为例. 城市观察, 2018, 55(3) : 131-138.

[42］世界自然基金会，一个地球自然基金会，中国科学院地理科学与资源研究所.粤港澳大湾区生态足迹报告 2019. (2019-07-18) [2020-0520].http://www.wwfchina. org/publications.

[43] 许堞，马丽. 粤港澳大湾区环境协同治理制约因素与推进路径. 地理研究, 2020,39(9) : 2165-2175.

[44] 张丽荣, 孟锐, 潘哲, 郑姚闽, 曾维华. 生态保护地空间重叠与发展冲突问题研究. 生态学报, 2019, 39(4)：1351-1360.

[45] 宫清华, 张虹鸥, 叶玉瑶, 袁少雄. 人地系统耦合框架下国土空间生态修复规划策略一一粤港澳大湾区为例. 地理研究, 2020, 39(9): 2176-2188

[46] 邓红蒂, 袁弘, 祁帆. 基于自然生态空间用途管制实践的国土空间用途管制思考. 城市规划学刊, 2020，(1)：23-30. 